\title{
A Representation of SDGs: Payments for Forest Environmental Services (PFES) in Loc Tien Commune, Phu Loc District, Thua Thien Hue Province
}

\author{
Mai Thi Khanh Van \\ School of Hospitality \& Tourism - Hue University \\ 22 - Lam Hoang - Hue City, Vietnam \\ Email: khanhvands@gmail.com
}

\begin{abstract}
In Vietnam, the policy on payment for forest environmental services (PFES) has been present for a long time, in the orientation of socialization of national forest protection. The role of this policy was not limited to the objective of environmental protection, the overarching objective of PFES has always been the link to develop the sector of environment, economy, and society. This has also been one of the targets of Goal 11: "Sustainable Cities and Communities" within the 17 Sustainable Development Goals (SDGs), set out by the United Nations. At the study site is Loc Tien commune, in Phu Loc district, Thua Thien Hue province, by in-depth interviews with local people and officials, the implementation of PFES, and its ability to meet the targets in Goal 11 were clarified. The PFES implementation mechanism has been well-established with the full range of stakeholders and their specific roles. However, the gained efficiency from PFES has not met the Vietnamese Government's goals that were to support positive economic, social, and environmental links. The aim to protect the forest environment has been implemented, however, the livelihoods and income of local communities have not improved visibly. In the future, to address current issues, policymakers should consider more solutions to advance the local livelihoods.
\end{abstract}

Keywords: Goal 11; Local livelihoods; Payment for forest environmental services; SDGs; Sustainable community. 


\section{Introduction}

Payment for environmental services (PES) is an environmental conservation tool that has been mentioned a lot in proving its benefitsin several aspects Miranda et al., 2003; Locatelli et al., 2008; Baker \& Rice, 2012). According to Wunder (2005), PES is a transaction between at least one seller and one buyer with environmental goods. The goals of PES are to preserve the environment, develop people's livelihoods, and enhance local economic value (Landell-Mills \& Porras, 2002; To et al., 2012; Pham et al., 2018). Sellers, in this case, are the objects, they have rights to manage and use environmental services (ES), and buyers are usually organizations and companies wishing to use ES. Currently, in the world as well as in Vietnam, ES buyers are mainly hydroelectricity, water supply companies, and tourism companies (Pham et al., 2013).

In Vietnam, PES exists as payment for forest environmental services (PFES), mainly, for transactions with hydropower and clear water companies (Pham et al., 2013; Nguyen et al., 2017). The Government of Vietnam has implemented PFES on a national scale in 2010, being the first country in Southeast Asia to do so (Pham et al., 2013). The desires of policymakers were to create a policy that could make effective development across all environmental, economic, and social aspects. Towards Sustainable Development Goals (SDGs), this government policy became consistent with one target of Goal 11: Sustainable Cities and Communities, specifically "support positive economic, social and environmental links between urban, peri-urban and rural areas by diverse national and regional development planning" (United Nations, 2020).

The providers of PFES are diverse, including communities, household groups, and households (Vietnam Government, 2010). In the case of Loc Tien commune, which belongs to Thua Thien Hue province, the PFES has been implemented in the forest of Thuy Duong village and the PFES provider has been the entire community of Thuy Duong village. As a result, the payment from PFES has been also paid to the whole community. Unlike the group of households or households, the role of individuals in the community for PFES is difficult to be calculated specifically. Therefore, the impact of PFES on the community also becomes more interesting to attract the researchers. The research questions are what is the impact of PFES on the community and how does PFES fit the Goal 11 of SDGs at the study site?

\section{Research Method}

Information related to PFES and the impact of it on local livelihoods at the research site was collected and processed to be used for this study. The field trip in Thuy Duong village was from January $2^{\text {nd }}, 2017$ to April, $30^{\text {th }}, 2017$. After that, the author collected and updated the information in September, 2019 and April, 2020 by calling for the interviewees.

The two sources of information used in this study are primary data and secondary data. Primary data was collected from two methods: Semi-structured interview and Depth-interview. Interviewees 
were official of the commune's people committee, official of the forest ranger unit, and households were randomly selected at the study site.

Interviewees would begin to answer with a short list of pre-prepared questions so that the interviewer can collect some general information about the subject. After that, in-depth interviews would be done as a conversation. The questions of in-depth interviews could flexibly change depending on the subject and the circumstances of the interview. However, the content of the interview always revolved around issues such as local livelihood and PFES process. (Table 1)

Table 1. List of interviewees and key interview questions

\begin{tabular}{ll}
\hline \multicolumn{1}{c}{ Interviewee } & \multicolumn{1}{c}{ Key interview questions } \\
\hline - 1 staff of Loc Tien & - Socio-economic background \\
Commune People's & - Implementation of PFES \\
Committee & - Status of community livelihoods \\
- 1 staff of Phu Loc & - Issues and concerns at the site level and \\
forest ranger unit & suggestions for the future \\
\hline - 20 households of & - History of village \\
Thuy Duong village & - PFES related livelihoods \\
& - Changes to local livelihoods induced by PFES \\
& - Issues and concerns and suggestions for the future
\end{tabular}

Source: Field survey $(2017,2019,2020)$

Secondary data has been collected from the People's Committee of Phu Loc district, Forest Protection Department of Phu Loc District, and Thua Thien Hue forest protection and development fund, as well as related studies and reports that have been published in newspapers, magazines and websites. 


\section{Research Findings}

\subsection{Overview of PFES Process in Loc Tien Commune}

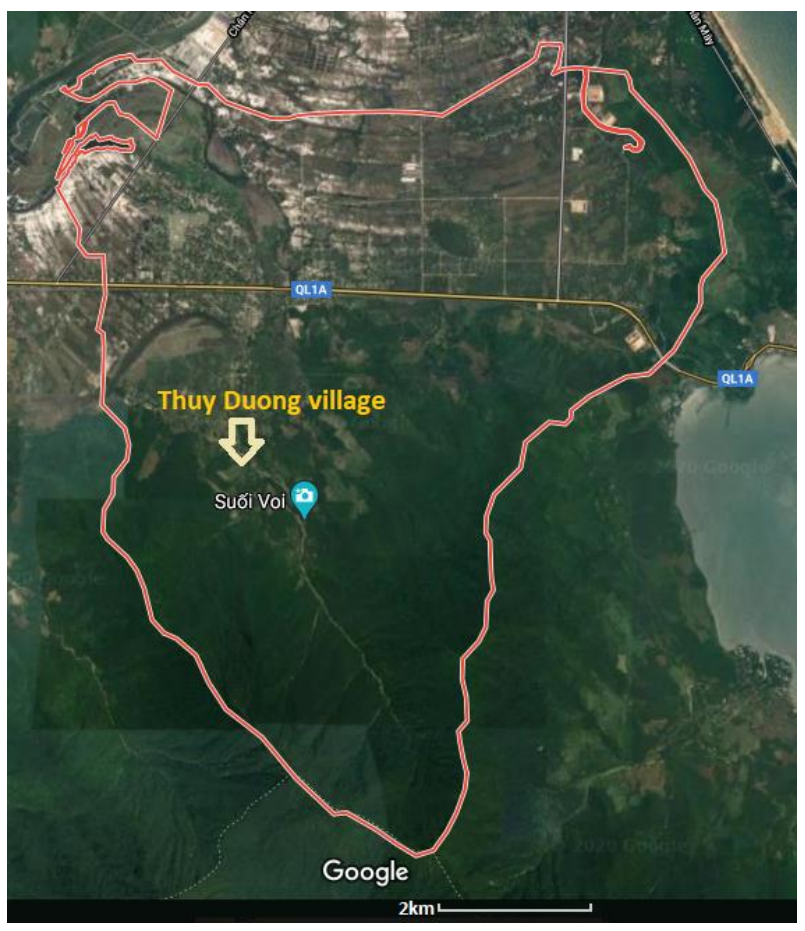

Figure 1. Map of Loc Tien commune and location of Thuy Duong village

Source: Google (2020)

In Loc Tien commune, there was only one community participating in PFES policy, that was Thuy Duong village (Figure 1). PFES implementation in Thuy Duong village has belonged to the process of PFES in Phu Loc district. This district was not on the list of piloting PFES policy under Decision No. 380 / QD-TTg dated April 10, 2008 of the Vietnam Prime Minister on the pilot policy of payment for forest environmental services. There, the PFES program started to be implemented at the time when Thua Thien Hue province implemented the PFES policy in 2011. From 2011 until 2013, policy-related activities mainly reviewed the situation and area of forests to develop payment options. Therefore, PFES payment activities have been started since 2014 .

About the implementation framework of PFES, the stakeholders of PFES and its implementation process were concerned. The stakeholders in the implementation of PFES policy, including the PFES provider, the PFES buyer, and some intermediary agencies which give advice and support to make sure the PFES process could go smoothly. In the case of Loc Tien commune, the roles of PFES stakeholders was illustrated in Figure 2. 




Figure 2. Process of PFES in Loc Tien commune

Source: Field survey $(2017,2019,2020)$

In Figure 2, the forest environmental service (FES) provider has been the Thuy Duong Community (as known as Thuy Duong village). This community was assigned to manage the forest area to be paid and provided the FES for the FES buyer. The FES buyer has been the Thua Thien Hue Water Supply Joint Stock Company which has to pay money for using the FES. Additionally, the role of Forest Protection and Development Fund of Thua Thien Hue (Hue FPDF) has accounted for the money needed from the FES buyer and received the money to pay for FES suppliers. The Phu Loc Forest Ranger Unit guided the Thuy Duong community when they had to prepare the PFES documents to submit the Hue FPDF.

In detail, the flow of PFES data would be done by the community with the guide of the Phu Loc Forest Ranger Unit. The head of the Thuy Duong village made a self-declaration of the result of forest protection to provide FES and send the dossier to the People's Committee of Loc Tien commune. After the Commune People's Committee checked, the PFES forest area of whole commune was calculated then sent to the Phu Loc Forest Ranger Unit. The Forest Ranger Unit completed the certification, and sent the Hue FPDF as a basis for mandated payment of PFES money for the plan year.

About the flow of the money, this was an indirect form of payment in the study case, the cash flow from the environmental service buyer would have to pass through the intermediary before the service seller could receive. Thua Thien Hue Water Supply Joint Stock Company has been the buyer of FES, so it had to pay PFES money to the service provider (Thuy Duong Communities and other FES providers were in the paid FES list of Phu Loc district). Hue FPDF received PFES money from Vietnam Forest Protection and Development Fund and paid the PFES money to forest owners - Thuy Duong community. 


\subsection{Paying PFES Money in Loc Tien Commune}

Among the five types of forest environmental services prescribed in Decree 99, one of them has implemented payment in Phu Loc district. It was the service of regulating and maintaining water sources for production and social life (water supply to Thua Thien Hue Water Supply Joint Stock Company).

Table 2. Information about PFES implementation in Loc Tien commune from 2014 to 2019

\begin{tabular}{lcccc}
\hline Yrea of forest & $\begin{array}{c}\text { Forest area to } \\
\text { FES supply (ha) } \\
\text { in PFES } \\
\text { program (ha) }\end{array}$ & $\begin{array}{c}\text { Unit price } \\
\text { (converted } \\
\text { forest area) }\end{array}$ & $\begin{array}{c}\text { Total Amount } \\
\text { (VND) }\end{array}$ \\
\hline 2014 & 584.00 & 584.00 & 100,000 & $58,400,000$ \\
\hline 2015 & 601.35 & 523.30 & 158,800 & $83,100,040$ \\
\hline 2016 & 601.35 & 523.30 & 165,132 & $86,413,575$ \\
\hline 2017 & 601.35 & 529.97 & 297,728 & $157,786,908$ \\
\hline 2018 & 604.84 & 465.27 & 400,000 & $186,108,000$ \\
\hline 2019 & 604.84 & 465.27 & 400,000 & $186,108,000$ \\
\hline
\end{tabular}

Source: Thua Thien Hue Provincial People's Committee (2014, 2015, 2016, 2017, 2018, 2019)

From Table 2, it showed that the forest area under PFES payment has increased over the years, from 584.00 ha in 2014 to 604.84 ha in 2019. This change was due to the adjustment process of the local authorities regarding the inter-forest area of PFES in Loc Tien commune. However, after the conversion of the forest area, the calculation of PFES money has not increased over the years. This was caused by the adjustments made in the calculation of the converted forest area according to Vietnamese government regulations ${ }^{1}$ as well as the changes in the classification of PFES-paid forest quality by local authorities. Regarding the unit price, this amount has been calculated and balanced by Thua Thien Hue Provincial People's Committee based on the PFES implementation situation in the whole province, thereby giving a specific unit price for each year. As an effort to increase PFES money to enable the local livelihoods from the PFES process, payment levels have increased over the years. As a result, the actual amount that the Thuy Duong community in Loc Tien commune received also increased each year, from VND 58 million in 2014 to VND 186 million in 2019, an increase of 320\%. 
The change in the converted forest area of Loc Tien commune could be further explained by the data in Table 3. Except in 2014, there was no difference between forest area in PFES program and forest area in FES supply (converted) because the Converted Coefficient (K1, K2) ${ }^{1}$ has not been applied. From 2015 onwards, the converted area was always much lower than the area of natural forest in the PFES payment list throughout Phu Loc district. There were two reasons for this discrepancy and all of them related to the $\mathrm{K}$ coefficients:

The first reason was related to the K1 coefficient (related by forest volume status): the forest area in Loc Tien commune in 2016 was mainly medium forest (332.72 ha, accounting for nearly $55.33 \%$ of the total area of 601.35 ha of the district forest) and the rest was poor forest (268.63 ha). Even in 2018, after changing the classification way, all of the forest area in this study case was poor forest. The reason that the poor forest area of Loc Tien commune increased from $44.67 \%$ to $100 \%$ was due to the adjustment based on current regulations. Because there was no rich forest area, the K1 coefficient was mainly 0.9 , leading to a decrease in the forest area after conversion.

The second reason was similar, related to the coefficient K2-purpose of forest use. In 2016, the communal forest area, there were 452.91 ha of protection forests (accounting for $75.32 \%$ ) and 148.44 ha of production forests (accounting for $24.68 \%$ ), without special-use forests. After two years, these figures changed to 600.41 ha protection forest (accounting for $99.27 \%$ ) and 4.43 ha production forest. Because of no special-use forest, the converted forest area was always lower than the natural forest area of Loc Tien commune. Table 3. Total area and types of forests protected in PFES policy of Loc

Tien commune

\begin{tabular}{|c|c|c|}
\hline Year & 2016 & 2018 \\
\hline Area of natural forest (ha) & 601.35 & 604.84 \\
\hline $\begin{array}{l}\text { Area contracted to manage and protect forests } \\
\qquad \text { (ha) }\end{array}$ & 601.35 & 604.84 \\
\hline
\end{tabular}

1 To calculate the payments to forest owners, the below formula has been used according to Decision 380 and Decree 99 (Prime Minister of Vietnam, 2008; Vietnam Government, 2010):

In there:

Total amount $(V N D)=$ Unit price $(V N D / h a) \times$ Area of forest $($ ha $) \times K$

- Total amount: Total amount paid to forest owner (VND)

- Unit price: Average fee per hectare of forest (VND/ha)

- Area of forest: Forest area managed for services (ha)

- K: coefficient $\mathrm{K}$ including:

- K1 (forest volume status): 0.9 for regrowth and poor forest; 0.95 for medium forest; 1.0 for rich forest

- K2 (forest function): 0.9 for production forest; 0.95 for protection forest; 1.0 for special-use forest

- K3 (origin of forest): 0.9 for plantation; 1.0 for natural forest

- K4 (difficulty of forest protection): 1.00 for very difficult; 0.95 for difficult; 0.90 for not very difficult 


\begin{tabular}{|c|c|c|c|}
\hline \multirow{3}{*}{$\begin{array}{c}\text { Classified by forest volume } \\
\text { status }\end{array}$} & rich & 0 & 0 \\
\hline & medium & 332.72 & 0 \\
\hline & poor & 268.63 & 604.84 \\
\hline \multirow{3}{*}{$\begin{array}{l}\text { Classified by forest } \\
\text { function }\end{array}$} & Production forest & 148.44 & 4.43 \\
\hline & Protection forest & 452.91 & 600.41 \\
\hline & Special-use forest & 0 & 0 \\
\hline
\end{tabular}

Source: People's Committee of Loc Tien Commune (2016); Phu Loc Forest Ranger Unit (2018)

\subsection{Using PFES Money in Loc Tien Commune}

From the data in Table 2, it showed that the amount of money the Thuy Duong community received from PFES has increased over the years. From about VND 58 million in 2014, this amount has more than tripled to VND 186 million in 2019. This was not a small amount of money and had the potential to become a source of capital to support economic development for the households in the community.

However, most of the money received from PFES was used for forest protection purposes. Payments from PFES would be paid by the community for activities such as:

- Patrolling and protecting the community forests;

- Propagating, disseminating and learning about conventions;

- Painting and revising the conventions on the protection of community forest;

- Paying for the managers of the Community Forest Protection Board;

- Training on fire prevention and reforestation techniques for all households in the community;

- Purchasing the protective equipment and items to support forest patrolling and protection: Costumes for forest protection and patrol; Machete; Water can; Electric speakers; Stationery...

- Paying for the risks when patrolling and protecting forests;

- Rewarding for people who participate effectively in forest protection, forest fire-prevention;

- Paying for community meeting (every 6 months);

- Supporting in planting non-timber forest products; (rarely)

From the above-mentioned expenditures, the annual amount of money received by the community from PFES was used to cover the costs of the forest protection. Because of that, the quality of forest under the management of Thuy Duong community was always ensured and there was no case of violating the regulations on forest management and protection. In detail, from 2014 to 2016, in the forest area managed by the community of Thuy Duong, the forest did not burn due to subjective causes; not to 
illegally exploit timber and non-timber forest products; there was no illegal deforestation to grow industrial trees, agricultural crops, and so on. The village community always ensured the measures to manage pests and diseases and prevented serious erosion of forest land. Therefore, in the acceptance record of paying for PFES implementation in 2016, the forest managed by the community of Thuy Duong village had a $100 \%$ good rate.

On the other hand, the support payments for households' economic development have not appeared in PFES expenditures. The only money people received from this policy was wages for forest protection patrols. However, this amount was very small and irregular, almost no impact on the improvement of the household's life. (Table 4)

Table 4. The daily wage for forest patrolling in Thuy Duong village

\begin{tabular}{|c|c|c|c|c|c|c|}
\hline Year & 2014 & 2015 & 2016 & 2017 & 2018 & 2019 \\
\hline $\begin{array}{l}\text { The daily wage } \\
\text { for patrolling/ } \\
\text { person/day } \\
\text { (VND) }\end{array}$ & 50,000 & 90,000 & 100,000 & 150,000 & 150,000 & 200,000 \\
\hline $\begin{array}{l}\text { Number of } \\
\text { patrol member/ } \\
\text { time (person) }\end{array}$ & 6 & 6 & 6 & 6 & 6 & 6 \\
\hline $\begin{array}{l}\text { Number of } \\
\text { patrol times / } \\
\text { month (times) }\end{array}$ & 2 & 2 & 2 & 2 & 2 & 2 \\
\hline
\end{tabular}

Source: Field survey $(2017,2019,2020)$

For the same reason, most people of working age in the village have worked away from home and have not participated in the policy. The members of forest protection patrols were mostly the elderly and people with poor health. As a result, forest protection activities have not also been favorable. The reason for this was that PFES money could not guarantee the lives of the locals, making their departure inevitable.

\subsection{Impacts of Implementation PFES on Local People}

When mentioning the impact of PFES policy implementation for the local people in Thuy Duong village (Loc Tien commune), it was impossible to simply mention the direct change of income. Because the income from the workdays involved in patrolling and checking the forest was not much. (Table 4) 
For the Community Forest Protection Patrol Team in Thuy Duong village, the daily wages of a person, from 2014 to 2019 was from VND 50-200,000 per person per day, this amount has risen over the years, however, it only reached about $50 \%$ of the daily income of local people. Patrol team members obtained when doing other jobs.

In the interview, Mr. Le Van Chien - a member of the community forest patrol team in Thuy Duong village also shared: "The payment for patrols was not much. But because of the responsibility of the village and the forest, whenever the head of the village calls, I have been ready to participate." This showed that, although income from PFES has been very little, this policy has had a positive effect on people's awareness of forest protection activities.

Forests protected by PFES policy were natural forests and could not be exploited arbitrarily. However, the exploitation of some small timber trees for non-commercial purposes and non-timber forest products has been allowed. Income from non-timber forest products (such as rattan, conical leaves, honey, and so on) was insignificant, mainly serving the needs of the exploiters. Households in the community could also exploit some of the trees from the forest area in PFES policy. However, they were only exploited for the purpose of building in the family, and in community. The harvesters were also limited in the number of harvested trees and needed permission from community forest management boards. Obviously, if the economic benefits of PFES policy only stopped at such small and erratic revenues, it would be difficult to make people willing to respond and wholeheartedly participate in patrol activities, management, and protection of forests.

However, the positive impact of PFES policies also came from the indirect benefits that forests bring. Specifically for the community in Thuy Duong village, Loc Tien commune, the forest has been maintained to help ensure the supply of water in the upstream for clean water company, the water in the middle to bring business opportunities for some households in Suoi Voi tourist site, and water downstream was an important factor for the agricultural production activities of the people.

Although the forests were not beneficial for the economic aspect until now, the local authority also had plans to improve the income of people who participated in PFES. In 2017, Thuy Duong community of Loc Tien commune planted additional native trees on bare land, which was the boundary between community forests and plantation forests of the people. In the future, other income sources may be earned due to the investment.

\subsection{The Fitness of PFES Process to Goal 11 of SDGs in Loc Tien Commune}

The study aimed to achieve the target "Support positive economic, social and environmental links between urban, peri-urban and rural areas by diverse national and regional development planning" in Goal 11 - Sustainable Cities and Communities. With a national policy that has been implemented for a long time, PFES has been expected to provide incentives for the economic, social, and environmental 
issues to be developed effectively in a sustainable way. In fact, the PFES policy has created a connection between the PFES users in urban and peri-urban areas and the PFES providers in rural areas. This linkage has taken place not only in this study case but also in all areas of Vietnam through the role of intermediaries such as the forest protection, the development funds and the forest protection units. The connection has occurred in both directions as indicated by monetary flows and forest environmental service flows.

However, when considering the combined impacts of three factors, which were social, economy, and environment, the PFES policy at the research site has not yet played its role to meet the target of the Goal 11. PFES has been expected to bring about sustainable development and mutual support in all three areas mentioned above. When implementing PFES, the quality of the forest environment has been better guaranteed due to the active protection of the local community. However, this did not seem to be accompanied by economic improvements for local communities who have been involved in providing PFES. Besides, people's awareness about their role in the PFES policy and forest protection task was quite good.

Unfortunately, they have had difficulty in maintaining the effectiveness of the forest protection patrol team as well as the ability to participate in PFES of the community. The reason was that they could not make a living by PFES, their livelihoods have not been guaranteed. Because the money they received from PFES has been spent mostly on forest protection activities and no longer has any money to spend on activities supporting local economic development. As a result, people of working age had to leave their communities to go to the big cities where they could earn income to cover the cost of living of their families. Therefore, the majority of people involved in the forest protection in the Thuy Duong community were the elderly. This led to a shortage of people to join the PFES process and the forest protection patrol team when the current members became too old or passed away.

Although the current situation has not had many positive signs, the local authorities were aware of that. They have been planning to help people improve their livelihoods from activities related to forestry. These activities have not been effective yet because they were only applied in a short time. However, these actions will be the grounds for the process of changing the application of PFES policies in an extra appropriate way, bringing better impacts to the local participants. In the future, PFES will be more and more effective and meet more than the targets set out in Goal 11 of SDGs.

\section{Conclusion}

PFES with indirect payment was carried out quite well in the Loc Tien commune. From the PFES implementation mechanism, the participation of local people has been guaranteed. With the good management of the local government and the voluntary spirit of the residents, the quality of the forest 
environment has been secured. People's awareness of PFES and forest protection have also become better after PFES implementation. This showed that PFES was an effective environmental policy.

However, there was still a gap between the PFES in expectation and in practice. As a result, the production of PFES has not fully benefited and it has not met with the expectation about improving the livelihood of the local community. The payment was still low and the income generating activities from forests was limited, making the local livelihoods not lean on the PFES money. Thus, the impacts of this policy on local people did not seem to be clear and not bring benefits to them as expected, except for increasing people's awareness about forest protection and PFES..

Regarding the relationship with SDGs, PFES in theory was completely consistent with goal 11 of SDGs. However, in reality, due to some constraints in implementation, a national plan such as PFES cannot be achieved by linking and supporting to achieve effective results in all three sides that are the environment, economy, and society. However, the research has found that the economic benefits from PFES were not large enough to create positive impacts on community income and livelihoods. Therefore, in the future, when the measures are created and the problem is resolved, PFES will be one of the tools to help Goal 11 of SDGs become realistic, so the goal of sustainable development will have many opportunities to come true.

From the actual implementation of PFES and its limitations to the improvement of local livelihoods, it is necessary to create measures to improve the situation to meet the goals of SDGs Goal 11. However, the replacement of an entirely new policy is not mandatory, there have already been models that successfully combine environmental protection and economic development owing to PFES in some areas of Vietnam. Therefore, the policymakers and local authorities can make some adjustments to change the PFES more appropriate to the initial three goals and follow the spirit of Goal 11. In this paper, the author has some suggestions to improve the PFES implementation in the study area as follows:

For monetary benefits from PFES, there are two methods that can be implemented simultaneously to increase the amount that people receive. First, based on the current nature tourism activities at the study site, it is possible to consider applying PFES in tourism, thereby increasing the total amount of PFES proceeds. Secondly, changing the scheme of the purpose of money used from PFES, paying more attention to the investment to support economic improvement for households participating in PFES.

For other benefits from PFES, the first option is giving to the allocation of wasteland areas around PFES forest to PFES providers. About this option, local authorities have begun to implement, however, it is advisable to link with agroforestry consulting institutions to ensure that the plans are carried out most effectively. For the second option, guiding the community to apply the economic development under PFES forest canopy should be considered. It is recommended to cultivate plants or 
raise animals that are local characteristics, have good quality, and are favored by consumers to ensure economic benefits. 


\section{References}

Baker, R. M., and Rice, J. (2012). Stakeholder perceptions of Mexico's payment for environmental services program: A comparative study of socioeconomic and environmental impacts in Oaxaca and Yucatan. Master's project, Nicholas School of the Environmental, Duke University.

Google map.

https://www.google.com/maps/place/L\%E1\%BB\%99c+Ti\%E1\%BB\%85n,+Ph\%C3\%BA+L\%E1 $\%$ BB $\% 99 \mathrm{c},+\mathrm{Th} \% \mathrm{E} 1 \% \mathrm{BB} \% \mathrm{ABa}+\mathrm{Thi} \% \mathrm{C} 3 \% \mathrm{AAn}+\mathrm{Hu} \% \mathrm{E} 1 \% \mathrm{BA} \% \mathrm{BF},+\mathrm{Vi} \% \mathrm{E} 1 \% \mathrm{BB} \% 87 \mathrm{t}+\mathrm{Nam} /$ @ 16.251307,107.9620235,12040m/data=!3m1!1e3!4m5!3m4!1s0x314188f5101a22e3:0x5ff4d51 837b4724d!8m2!3d16.2540793!4d107.9887402?hl=vi-VN (Retrieved 15 April 2020)

Miranda, M., Porras, I.T., and Moreno, M. L. (2003). The social impacts of payments for environmental services in Costa Rica: A quantitative field survey and analysis of the Virilla watershed. International Institute for Environment and Development, London.

Nguyen, V.H., Hoang, T.H., and Nguyen, H.N. (2017). Payment for Forest Environmental Services in Tourism in Vietnam.

https://www.researchgate.net/publication/321011344_Payment_for_Forest_Environmental_Servi ces_in_Tourism_in_Vietnam (Retrieved 25 February 2020)

Landell-Mills, N. and Porras, T. I. (2002). Silver bullet or fools' gold? A global review of markets for forest environmental services and their impact on the poor. Instruments for sustainable private sector forestry series. International Institute for Environment and Development, London.

Locatelli B., Rojas V. and Salinas Z. (2008). Impacts of payments for environmental services on local development in northern Costa Rica: A fuzzy multi-criteria analysis. Forest Policy and Economics 10: $275-285$.

People's Committee of Loc Tien commune (2016). Statistical table of area and current situation when contracted to protect and manage forests in 2016 in Phu Loc district water basin. Loc Tien commune.

Pham, T. T., Bennett, K., Vu, T. P., Brunner, J., Le Ngoc, D., and Nguyen, D. T. (2013). Payments for forest environmental services in Vietnam: from policy to practice. CIFOR Occasional Paper, (93).

Pham, T. T., Bui, T. M. N., Dao, T. L. C., Hoang, T. L., Pham, H. L., and Nguyen, V. D. (2018). The role of Payment for Forest Environmental Services (PFES) in financing the forestry sector in Vietnam. CIFOR Infobrief, (222).

Phu Loc Forest Ranger Unit (2018). Statistical table of the area providing forest environment services in 2018. Phu Loc district. 
Prime Minister of Vietnam (2008). Decision 380 / QD-TTg on the pilot policy of payment for forest environmental services. Ha Noi city.

Thua Thien Hue Provincial People's Committee (2014, 2015, 2016,2017,2018,2019). Decision on Approving PFES Plan of Thua Thien Hue Province in 2014, 2015, 2016, 2017, 2018, 2019. Hue city.

To, P. X., Dressler, W. H., Mahanty, S., Pham, T. T., and Zingerli, C. (2012). The prospects for payment for ecosystem services (PES) in Vietnam: a look at three payment schemes. Human ecology, 40(2): 237-249.

United Nations (2020). https://www.un.org/sustainabledevelopment/cities/ (Retrieved 20 March 2020)

Vietnam Government (2010). Decree No. 99/2010 / ND-CP on policies of payment for forest environmental services. Ha Noi city.

Wunder, S. (2005). Payments for environmental services: some nuts and bolts. CIFOR Occasional paper 42. Center for International Forestry Research, Bogor, Indonesia. 